\title{
Selected aspects of application of dual fuel marine engines
}

\begin{abstract}
The paper presents examples of application of dual fuel marine engines based on the expertise of the largest marine engine manufacturers. The fueling systems of these engines have been presented as fueled with fuel gases in various combinations with liquid fuels. Examples of the application of dual fuel engines in vessels as well as variants of the powertrains have been shown. The results of own simulation research (Monte Carlo method) have also been presented related to the $N \mathrm{O}_{x}$ emission from a variety of vessels operating in the area of the Bay of Gdansk proving that the use of engines fueled with fuel gas may indeed reduce the emission of $N_{x}$ from marine vessels operating in this area.
\end{abstract}

Key words: dual fuel engine, ship, emission, toxic compounds

\section{Wybrane aspekty stosowania okrętowych dwupaliwowych silników spalinowych}

W artykule podano przyklady zastosowania silników dwupaliwowych do napędu statków morskich w świetle doświadczeń największych firm produkujacych silniki okrętowe. Przedstawiono stosowane sposoby zasilania tych silników paliwem gazowym w różnych wariantach kojarzenia go z zasilaniem paliwem cieklym. Podano przykłady zastosowania silników dwupaliwowych $w$ siłowniach okrętowych $i$ warianty stosowanych układów napędowych. Podano również wyniki własnych badań symulacyjnych (metodą Monte Carlo) natężenia emisji tlenków azotu z różnego rodzaju statków morskich pływajacych w rejonie Zatoki Gdańskiej, wykazujac, że zasilanie silników paliwem gazowym może spowodować istotne zmniejszenie natężenia emisji tlenków azotu ze statków operujacych w tym rejonie.

Słowa kluczowe: silnik dwupaliwowy, statek, emisja, zwiąki toksyczne

\section{Introduction}

A decisive factor related to the increase of the use of fuel gases in marine vessels has always been the necessity of a reasonable utilization of large amounts of gas evaporating from the cargo gas transported in the vessels. It is estimated that the amount of the evaporated gas, depending on the hydro-meteorological conditions of the vessel is $0.1 \%$ to $0.3 \%$ of the volume of the transported cargo. For an LNG carrier of the capacity of $100.000 \mathrm{~m}^{3}$ the evaporation rate may reach approximately $300 \mathrm{~m}^{3}$ (approximately 138 tons) of gas per day. Such an amount of gas is sufficient to power the engine of the power output of $35 \mathrm{MW}$ [1]. This is how the natural conditions for the development of gas fueled marine engines formed, particularly since the combustion of evaporating gas in marine boilers is uneconomical.

If a fuel gas is used for the fueling of marine engines all the engines' advantages are preserved (high efficiency in particular) as well as other benefits such as:

- reduced exhaust emissions and reduced tar deposits in the combustion chamber,

- non-occurrence of fuel-based lubricant dilution,

- a significant reduction of sulfur corrosion,

- better combustion from the point of view of the gas/air mixing, thus ensuring homogeneity of the charge,

- reduction of thermal loads of the engine components.

An important role also plays the low cost of the fuel gas. Partly belittled by the elevated operating costs, it still turns out positive in the overall economic balance of the transport task.

Gas-fueled engines, dual fuel in particular, fueled alternatively with a liquid or gaseous fuels or both at the same time

\section{Wprowadzenie}

Decydujące znaczenie w zwiększaniu zastosowania paliw gazowych w statkach morskich miała konieczność racjonalnego wykorzystania dość znacznej ilości gazu odparowującego z gazu przewożonego w zbiornikach statków. Szacuje się, że ilość odparowanego gazu, zależnie od warunków hydrometeorologicznych pływania statku, wynosi od $0,1 \%$ do $0,3 \%$ objętości przewożonego ładunku. Dla gazowca LNG o pojemności ładunku wynoszącej 100 tys. $\mathrm{m}^{3}$ intensywność odparowania może wynosić ok. $300 \mathrm{~m}^{3}$ (ok. 138 ton) gazu w ciągu doby. Taka ilość gazu wystarcza do zasilania silnika napędowego o mocy $35 \mathrm{MW}$ [1]. W ten sposób powstały niejako naturalne warunki rozwoju silników okrętowych zasilanych paliwem gazowym, tym bardziej że spalanie gazu odparowanego z ładunku w kotłach okrętowych jest nieekonomiczne.

W sytuacji zastosowania paliwa gazowego do zasilania silników okrętowych zostają zachowane wszystkie jego zalety (przede wszystkim wysoka sprawność), uzupełnione o inne korzyści, takie jak:

- zmniejszona emisja toksycznych składników spalin i mniejsza ilość osadów nagaru w komorze spalania,

- niewystępowanie rozcieńczania paliwem oleju smarowego,

- znaczne ograniczenie korozji siarkowej,

- lepsze spalanie z punktu widzenia łatwości mieszania się gazu z powietrzem, a tym samym zapewnienia jednorodności mieszaniny paliwowo-powietrznej,

- zmniejszenie obciążeń cieplnych elementów konstrukcyjnych silnika.

Bardzo dużą rolę odgrywa również niski koszt jednostkowy paliwa gazowego, który, choć skompensowany czę- 
Gas-diesel (GD) engines:

- Runs on various gas / diesel mixtures or alternatively on diesel.

- Combustion of gas, diesel and air mixture in Diesel cycle.

$-$ Combustion of gas and air mixture in Otto cycle, triggered by spark plug ignition.
Spark-ignition gas (SG) engines:

- Runs only on gas.

\footnotetext{
- High-pressure gas injection.

- Low-pressure gas admission.

- Low-pressure gas admission.
}

\author{
Dual-fuel (DF) engines: \\ - Runs on gas with $1 \%$ diesel \\ (gas mode) or alternatively on \\ diesel (diesel mode). \\ - Combustion of gas and air \\ mixture in Otto cycle, triggered \\ by pilot diesel injection (gas \\ mode), or alternatively \\ combustion of diesel and air \\ mixture in Diesel cycle (diesel \\ mode).
}

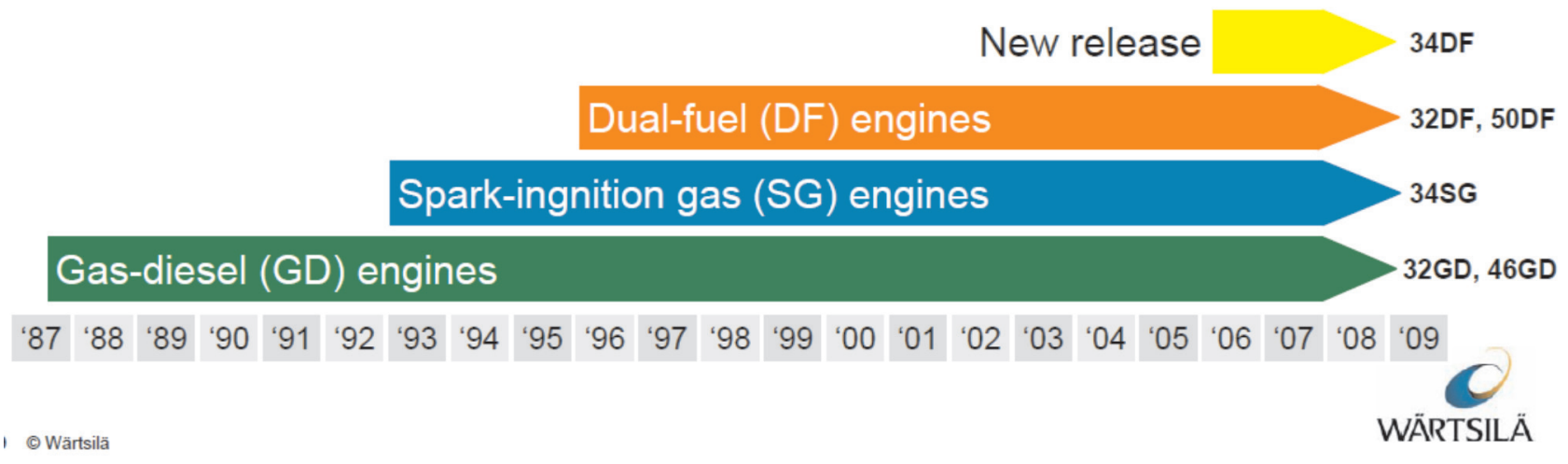

Fig. 1. Development of the gas engine technologies by Wärtsilä [3]

Rys. 1. Rozwój technik silników gazowych firmy Wärtsilä [3]

are more and more widely applied in marine vessels. In the years 2007-2009 MAN Burmeister \& Wain installed on 20 LNG carriers 40 dual fuel engines of the total power output of $746 \mathrm{MW}$ [2]. In the same period Wärtsilä installed 96 dual fuel engines on LNG carriers and 15 dual fuel engines on other vessels [3]. The schematic view of the development of gas fueled engines of this company has been shown in Fig. 1.

\section{Methods of gas engine fueling}

Modern marine engines, due to the pressure of the gas delivered to the cylinder are classified as low pressure, where the fuel gas of the pressure of $(0.3-0.5) \mathrm{MPa}$ is fed to the cylinder in the initial phase of the compression stroke and high pressure where the gas in a liquefied form is fed to the cylinder at the pressure of approximately $25 \mathrm{MPa}$ at the end of the compression stroke.

Low-pressure gas fueling systems were used in older marine engines. In these engines the fuel was fed through a separate conduit directly to the intake duct of the cylinder (Fig. 2 and 3 ). The growing power output of marine engines, hence large volumes of the air fuel mixtures as well as high volumes of the intake duct pose a serious threat of uncontrolled fire in case of the mixture self ignition. In high pressure fueling systems in two-stroke engines the gas is fed to the cylinder with a separate conduit through a valve in the cylinder head. The conduit is fitted with a safety valve and a flame damper. In marine medium speed four stroke engines the gas is fed to the cylinder through a controlled gas valve located in the cylinder head. ściowo przez zwiększone koszty eksploatacyjne, odgrywa pozytywną rolę w całkowitym bilansie przedsięwzięcia transportowego.

Silniki gazowe, zwłaszcza dwupaliwowe ( $D F-D u a l$ Fuel), zasilane alternatywnie paliwem płynnym lub gazowym, albo jednym i drugim paliwem jednocześnie, znajdują coraz większe zastosowanie w okrętownictwie. W latach 2007-2009 firma MAN Burmeister \& Wain zainstalowała na 20 zbiornikowcach LNG 40 silników dwupaliwowych o łącznej mocy $746 \mathrm{MW}$ [2]. W analogicznym okresie firma Wärtsilä zainstalowała 96 silników dwupaliwowych na zbiornikowcach LNG i 15 silników dwupaliwowych na statkach innego typu [3]. Schematyczne ujęcie rozwoju silników gazowych tej firmy przedstawiono na rys. 1.

\section{Sposoby zasilania silnika paliwem gazowym}

Współczesne silniki okrętowe, ze względu na wartość ciśnienia gazu doprowadzanego do cylindra, dzielą się na niskociśnieniowe, w których paliwo gazowe o ciśnieniu $(0,3$ - 0,5) MPa doprowadzane jest na początku suwu sprężania, i wysokociśnieniowe, w których paliwo gazu skroplonego w postaci ciekłej, przy ciśnieniu ok. $25 \mathrm{MPa}$, doprowadzane jest pod koniec suwu sprężania w cylindrze silnika.

Niskociśnieniowe systemy zasilania silnika gazem stosowane były w starszego typu silnikach okrętowych. W silnikach tych paliwo gazowe doprowadzane jest oddzielnym przewodem bezpośrednio do kanału dolotowego cylindra (rys. 2 i 3). Rosnące moce silników okrętowych, a zatem i 


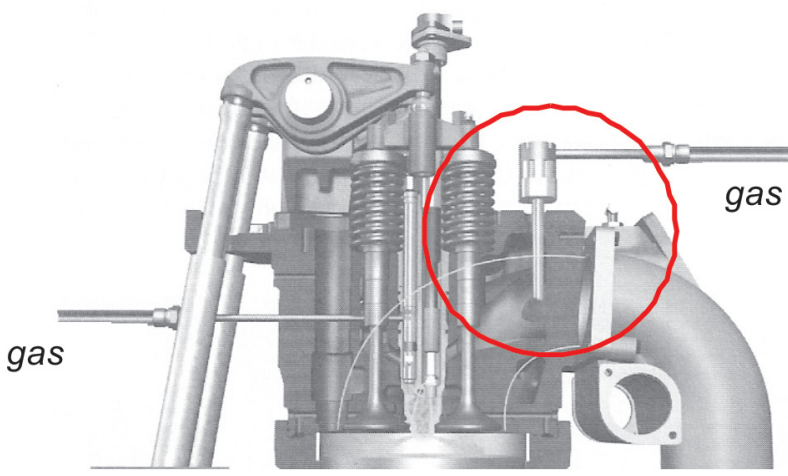

Fig. 2. Fuel gas system in the Wärtsilä 20V34SG engine [5]

Rys. 2. Układ zasilania paliwem gazowym silnika firmy Wärtsilä tури 20V34SG [5]

In high-pressure gas fueling systems the gas is fed to the valve located in the cylinder head. This valve is fitted as a separate system or is a part of the injector supplying the pilot dose of liquid fuel (Fig. 4). Irrespective of the above configuration the valve is fitted with a needle that shuts the gas flow to the cylinder, whose displacement is realized through pressure pulses from a separate system [4].

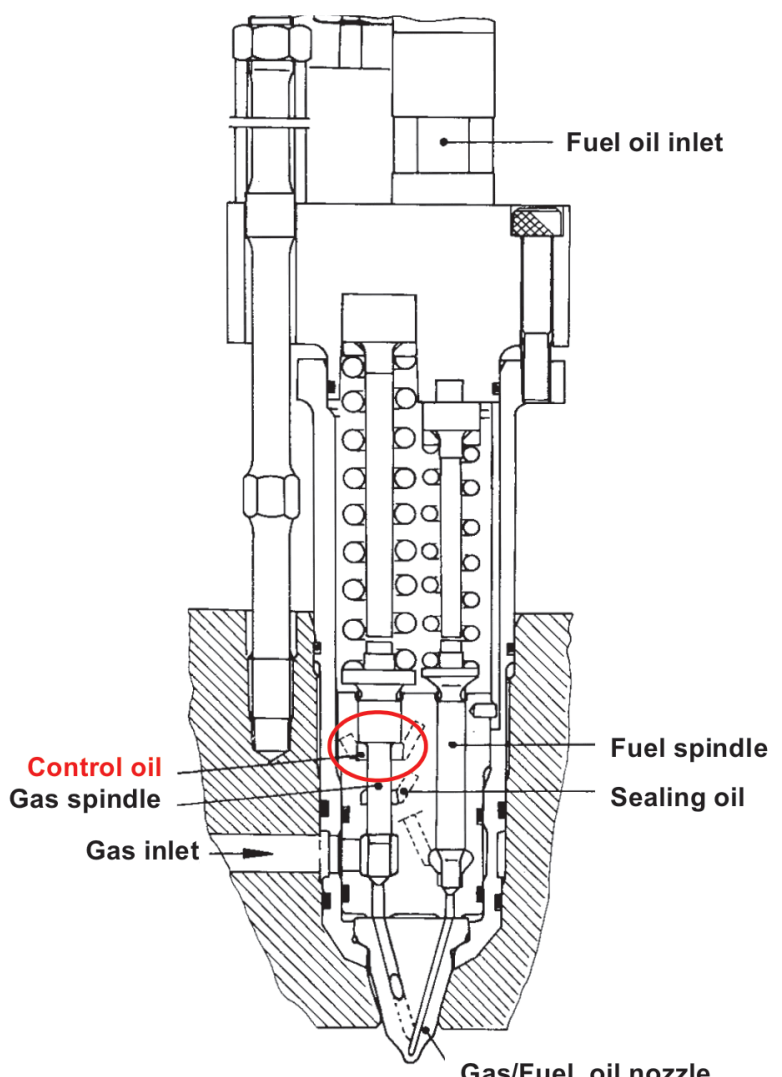

Fig. 4. Cross-section of the combined injector - diesel/gas by MAN L35MC with the gas-controlling element marked [5]

Rys. 4. Przekrój wtryskiwacza kombinowanego olej napędowy/gaz silnika firmy MAN typu L35MC z zaznaczonym elementem sterujacym przepływem gazu [5]

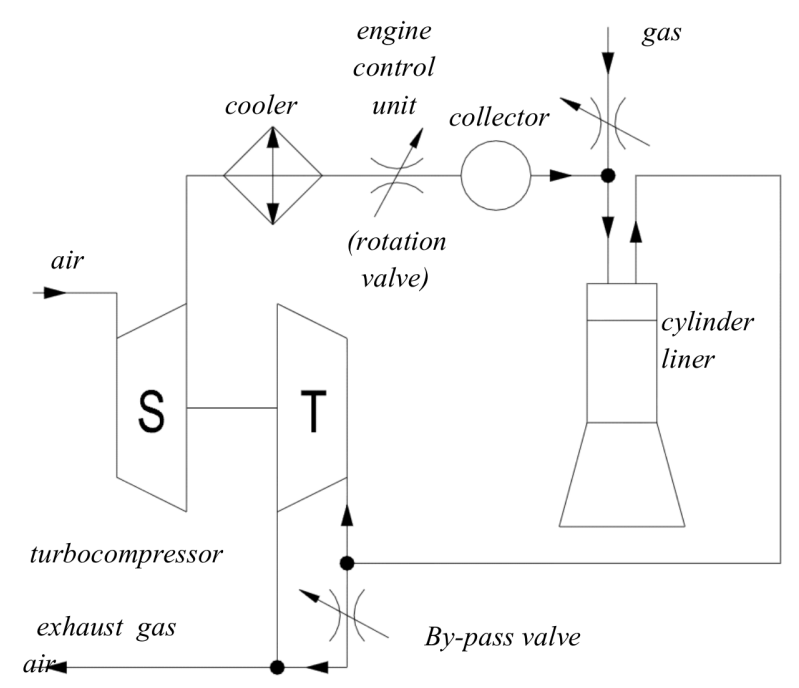

Fig. 3. Schematics of gas feed in the intake duct of the cylinder [4] Rys. 3. Schemat zasilania gazem $w$ kanale dolotowym cylindra [4]

obszerne objętości mieszaniny paliwa i gazu, i duże objętości kanału dolotowego w obszernym kanale dolotowym stwarzają wielkie zagrożenie pożarowe w przypadku samozapłonu mieszaniny. W niskociśnieniowych systemach zasilania gazem silników dwusuwowych gaz doprowadzany jest do cylindra oddzielnym przewodem poprzez zawór umieszczony w głowicy. Przewód wyposażony jest w zawór bezpieczeństwa i tłumik płomienia. W okrętowych średnioobrotowych silnikach czeterosuwowych gaz doprowadza się do cylindra przez sterowany zawór gazowy umieszczony w głowicy.

W wysokociśnieniowych systemach doprowadzania gazu, gaz jest doprowadzany do zaworu umieszczonego w głowicy silnika. Zawór ten montowany jest jako oddzielny zespół lub stanowi część wtryskiwacza podającego dawkę pilotującą paliwa ciekłego (rys. 4). Niezależnie od sposobu montażu zawór ten posiada iglicę zamykającą dopływ gazu do cylindra, której ruch jest realizowany za pomocą impulsów ciśnienia z oddzielnego systemu [4].

Przykładem dwupaliwowych silników okrętowych wyposażonych w wysokociśnieniowy system doprowadzania paliwa gazowego jest silnik Sulzer typoszeregu RTA. Silnik ten został przystosowany do zasilania dwupaliwowego poprzez zmiany konstrukcyjne silnika zasilanego wyłącznie paliwem ciekłym. Zmiany te obejmowały:

- umieszczenie w głowicy cylindrowej dwóch dodatkowych zaworów wtryskowych paliwa gazowego,

- wyposażenie silnika w dodatkową pompę sterującą zaworami gazowymi umieszczonymi w głowicach oraz $\mathrm{w}$ dodatkowy system kontroli obciążenia silnika,

- wyposażenie silnika w system bezpiecznego doprowadzania gazu od sprężarki wysokociśnieniowej do zaworów w głowicy silnika.

\section{System zapłonu mieszaniny palnej gaz-powietrze}

W miarę zwiększania rozmiarów cylindra silników okrętowych wzrasta zapotrzebowanie na energię niezbędną do 
An example of a dual fuel marine engine fitted with a high-pressure fuel gas feeding system is the Sulzer (type-series RTA) engine. This engine has been adapted for dual fueling through modifications in its original (liquid fuel) design. These changes included:

- fitting of two additional gas injector valves in the cylinder head,

- fitting the engine with an additional pump that controls the gas valves located in the cylinder head and an additional engine load control system,

- fitting the engine with a safe fuel gas supply system from the high pressure compressor to the valves in the cylinder head.

\section{The mixture (air/gas) ignition system}

As the diameter of the cylinders in marine engines grows the demand for energy needed for the ignition of the mixture increases. The use of spark ignition gas engines (SG) forces an application of complex cylinder heads with a pre-chamber (Fig. 5). An additional element needed for the ignition is the spark plug of a special design.

Another solution is the application of a dual fuel system (DF) with an injection of a pilot dose of liquid fuel (diesel oil) ensuring a sufficient energy of mixture ignition still preserving the combustion chamber typical of a self-ignition engine (Fig. 6). Besides this system allows engine operation on diesel fuel exclusively should the gas system fail [4]. In the latest solutions of dual fuel engines we can find three basic fuel supply systems:

- liquid fuel and fuel gas are fed through a single injector,

- liquid fuel and fuel gas are fed through separate systems,

- there is one injector fitted with two nozzles - one for the main feed of the liquid fuel - traditional hydraulic injection system, the other - for the pilot injection in the common rail system.

The first fueling solution was applied in the Wärtsilä 32GD engine [6]. The fuel is injected through three jets placed
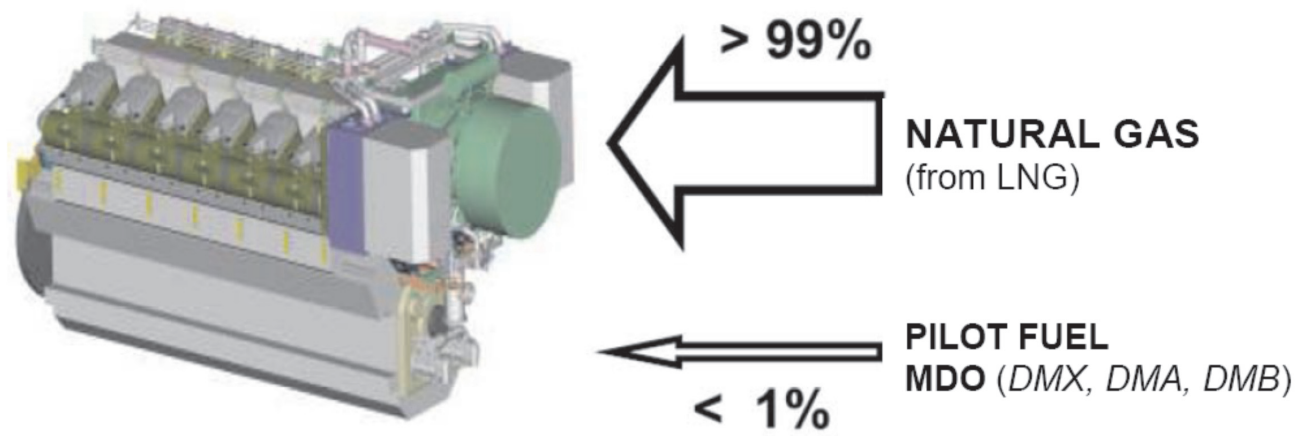

Fig. 6. Example of fueling in a dual fuel system (DF) with a pilot injection of diesel oil [2] Rys. 6. Przyktad zasilania silnika w uktadzie dwupaliwowym (DF) z wtryskiem pilotowym oleju napędowego [2] 
a.

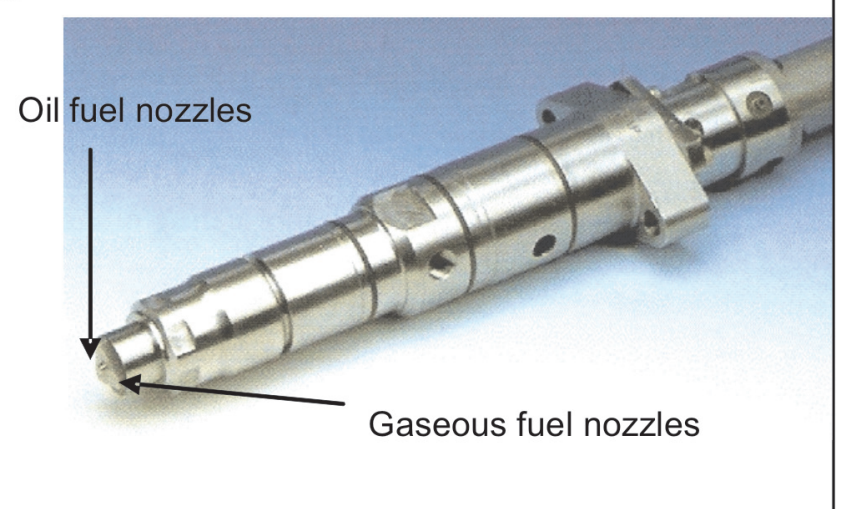

b.

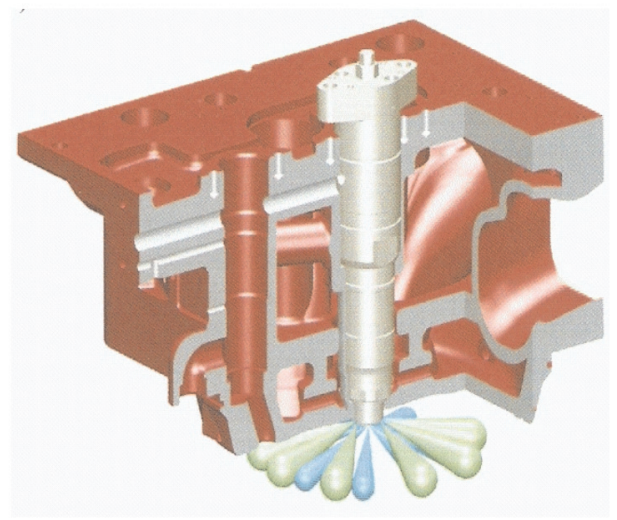

Fig. 7. The fuel injector in the Wärtsilä 32GD engine (a) and the schematics of the distribution of the injected fuel (b) [6] Rys. 7. Wtryskiwacz paliwa silnika firmy Wärtsilä typu 32GD (a) i schemat rozkładu wtryskiwanego paliwa (b) [6]

on the tip of a triangle at the injector nozzle (Fig. 7a). Each jet has three holes thus during the injection we obtain 9 streams of injected gas. The injection of diesel oil takes place before the gas is injected by the 9 holes placed on the injector axis that supply fuel between the gas streams (Fig. 7b).

During the operation of the Wärtsilä 32GD engine in the 'gas-liquid fuel' mode (GD) the fuel gas is the main source of energy and the pilot injection of diesel oil (approximately $5 \%$ of the total dose) is there only for the initiation of the combustion process [6]. The GD fuel mode (Fig. 8) is available for the range of loads $(0.3-1.0) \mathrm{P}_{\mathrm{n}}$ and the fuel gas is injected under the pressure of $35 \mathrm{MPa}$. The fuel sharing mode (FS) is available for the range of loads between $35 \% \mathrm{P}_{\mathrm{n}}$ and $100 \% \mathrm{P}_{\mathrm{n}}$. The fuel sharing point can be adjusted continuously from the WOIS control module (Wärtsilä Operating Interface System). This mode allows a simultaneous combustion of the fuel gas and diesel oil while the share quantities are flexibly adjustable (in the fuel sharing area FS - Fig. 8).

Above and below the FS mode there is a Transfer Window where the engine working point occurs only for a brief moment, while the operating modes are changed.

In reference to the already mentioned application of a single injector with two nozzles (one for the main fueling with liquid fuel in a traditional hydraulic injection and the other for the pilot dose in the a common rail system of the injection pressure of $100 \mathrm{MPa}$ ) it is possible to reduce the pilot dose up to $1 \%$ of the total fuel dose [2-4].
- zastosowanie jednego wtryskiwacza paliwa zaopatrzonego w dwie końcówki - jedną do zasadniczego zasilania paliwem ciekłym - w tradycyjnym systemie wtrysku hydraulicznego, drugą - dawki pilotowej w systemie common rail.

Pierwsze rozwiązanie zasilania paliwem zastosowano w silniku firmy Wärtsilä typu 32GD [6]. Paliwo wtryskiwane jest przez 3 dysze umieszczone na wierzchołkach trójkąta na końcówce wtryskiwacza (rys. 7a). Każda dysza ma 3 otwory, tak więc podczas wtrysku tworzy się 9 strumieni gazu. Wtrysk oleju napędowego następuje przed rozpoczęciem wtrysku gazu przez 9 otworów umieszczonych w osi wtryskiwacza, dostarczających paliwo pomiędzy strumienie gazu (rys. 7b).

Podczas pracy silnika Wärtsilä typu 32GD w tzw. trybie „gaz-paliwo ciekłe (GD)” paliwo gazowe jest głównym źródłem energii, dawka pilotowa oleju napędowego (około 5\% dawki całkowitej) służy jedynie zapoczątkowaniu procesu

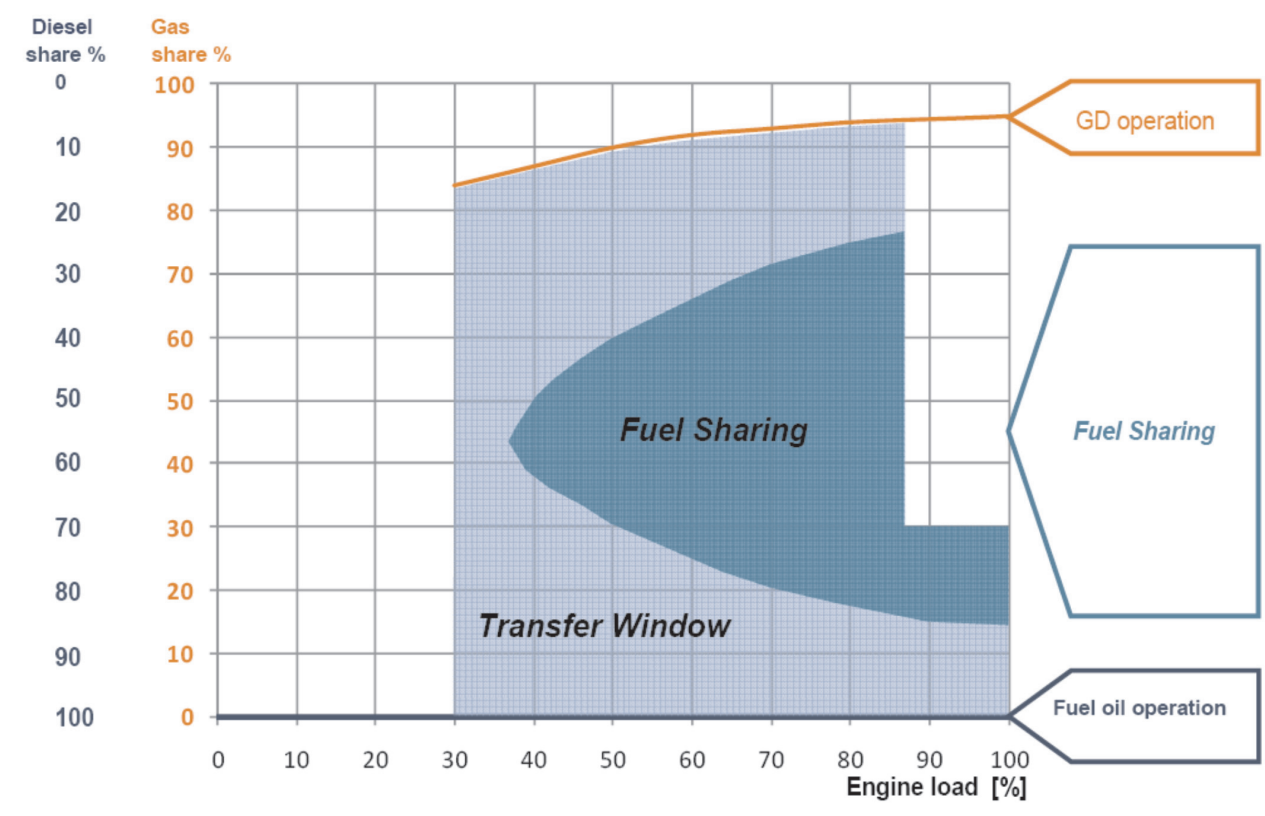

Fig. 8. Engine operating mode Wärtsilä 32GD [6]

Rys. 8. Tryby pracy silnika Wärtsilä 32GD [6] 


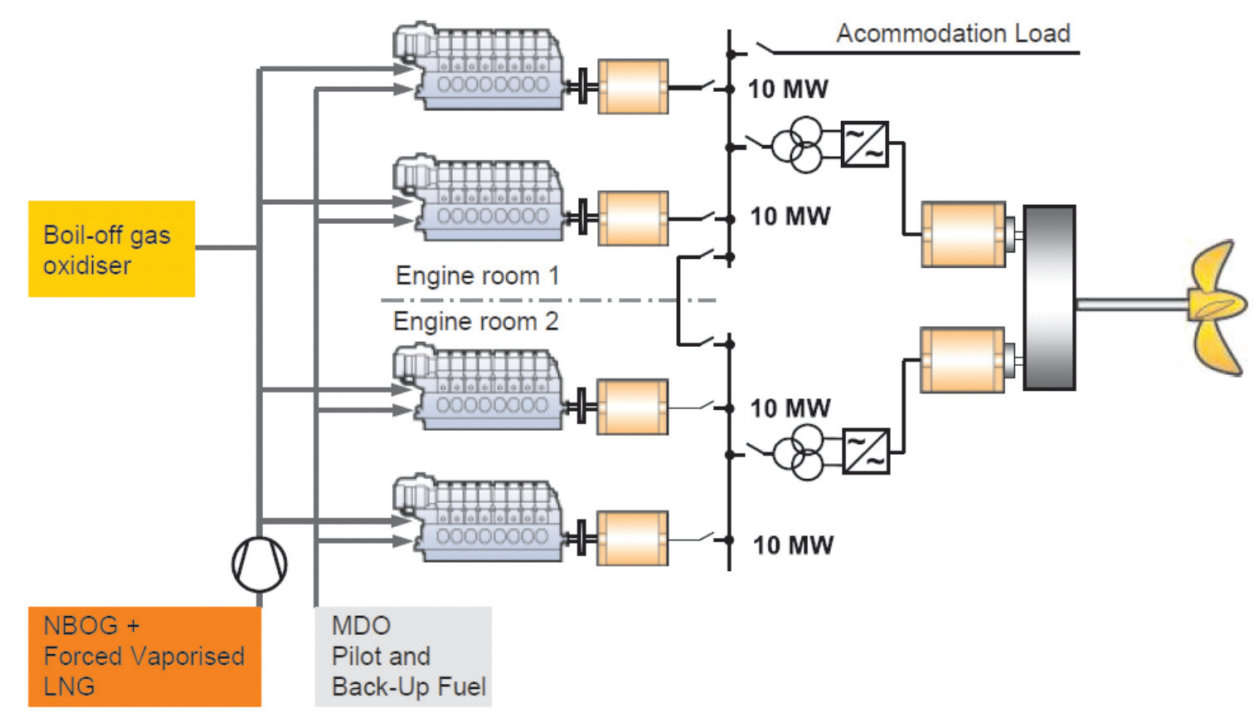

Fig. 9. Example of Dual-Fuel-Electric system for an LNG carrier by MAN (N-BOG - naturally evaporated gas; F-BOG forced evaporation; MDO - Marine Diesel Oil) [2]

Rys. 9. Przyktad rozwiązania siłowni Dual-Fuel-Electric napędu gazowca LNG firmy MAN (N-BOG-gaz odparowany naturalnie; F-BOG gaz pozyskany w sposób wymuszony; MDO-Marine Diesel Oil - okrętowy olej napędowy) [2]

\section{Examples of solutions of marine powertrains with the use of dual fuel engines and their influence on the exhaust emissions}

The application of dual fuel engines seems particularly attractive for LNG carriers transporting liquefied natural gas (LNG) as the evaporated gas BOG (Boil of Gas) from the transported cargo is used as engine fuel. This allows a reduction of a very complex and costly process of repeated liquefaction of the gas and a reduction of the cargo residues.

In reference to the LNG carriers due to the economic criteria such as fuel cost, fuel consumption, reduction of the size of the engine rooms, thus expanding the cargo bay engine manufacturers (particularly MAN Diesel and Wärtsilä) have proposed the use of engine rooms fitted with power generators driven by dual fuel engines. The power generated in such a way is supplied to the electric motors that drive the ship's propellers (DualFuel-Electric). An example of such an engine room has been shown in Fig. 9.

Another solution is the use of a Dual-FuelMechanic system where the dual fuel two or four stroke engines drive the adjustable or non-adjustheavy fuel oil) [2] gaz; HFO - paliwo okrętowe ciężkie) [2] spalania [6]. Tryb pracy GD (rys. 8) możliwy jest dla zakresu obciążeń $(0,3-1,0) \mathrm{P}_{\mathrm{n}}$, przy czym paliwo gazowe wtryskiwane jest pod ciśnieniem $35 \mathrm{MPa}$. Tryb „dzielenia paliw" (FS - Fuel Sharing) możliwy jest dla zakresu obciążeń silnika pomiędzy $35 \% \mathrm{P}_{\mathrm{n}}$ a $100 \%$ $\mathrm{P}_{\mathrm{n}}$. Punkt podziału paliw może być nastawiany w sposób ciągły z modułu sterowania WOIS (Wärtsilä Operating Interface System). Tryb ten pozwala na jednoczesne spalanie paliwa gazowego i oleju napędowego, a proporcje ilościowe można regulować elastycznie (w obszarze pola ,dzielenia paliwa" FS - rys. 8).

Powyżej i poniżej obszaru trybu FS znajduje się tzw. „okno przenoszenia" TW (Transfer Window), w którym punkt pracy silnika może znaleźć się jedynie chwilowo, podczas zmiany trybu pracy.

W odniesieniu do wspomnianego już zastosowania jednego wtryskiwacza paliwa zaopatrzonego w dwie końcówki - jedną do zasadniczego zasilania paliwem ciekłym w tradycyjnym systemie wtrysku hydraulicznego, drugą - dawki pilotowej w systemie common rail (ciśnienie wtrysku wynosi $100 \mathrm{MPa}$ ) możliwe jest ograniczenie dawki pilotowej nawet do $1 \%$ dawki całkowitej [2-4].

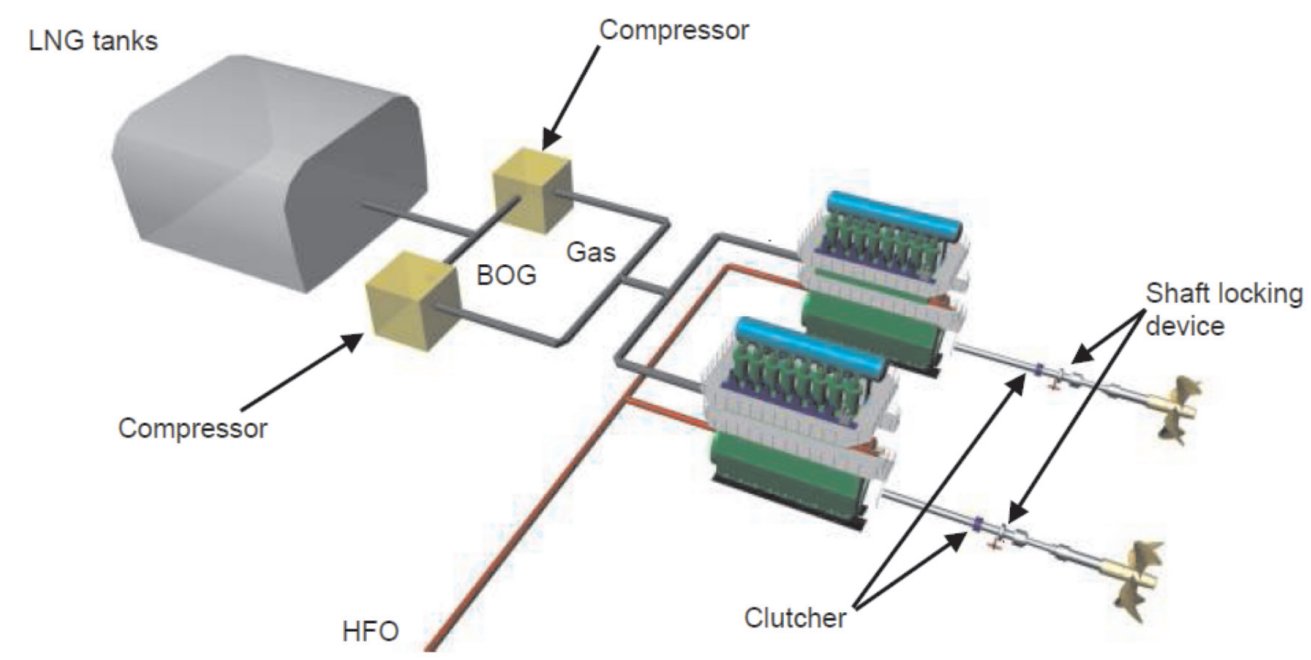

Fig. 10. Example of a Dual-Fuel-Mechanic system for the LNG carrier by MAN (BOG - evaporated gas; HFO -

Rys. 10. Przykład rozwiazania siłowni Dual-Fuel-Mechanic napędu gazowca LNG firmy MAN (BOG - odparowany 


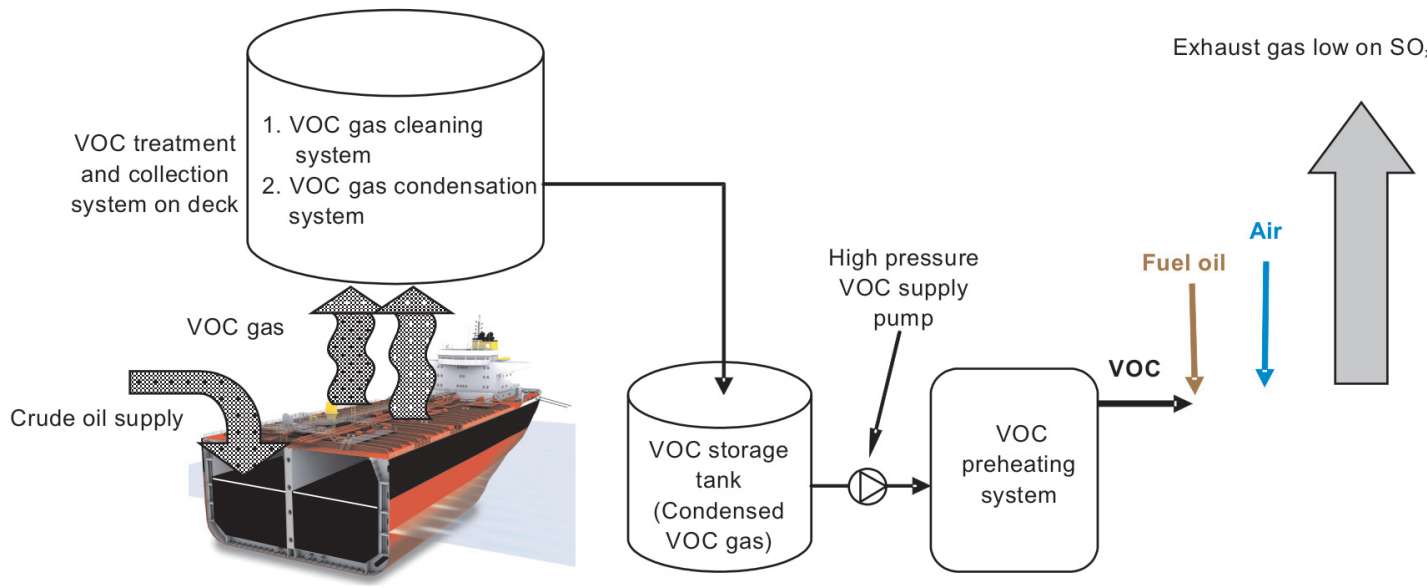

Fig. 11. Schematics of fueling of the dual fuel engine with volatile organic compounds (VOC's)

Rys. 11. Schemat zasilania silnika dwupaliwowego odparowanymi lotnymi zwiazkami organicznymi (VOC's)

able propellers. An example of an engine room with two dual fuel engines two-stroke low speed engines by MAN Diesel MC-C/ME-C/ME-GI driving two propellers has been shown in Fig. 10 [2].

A specific form of a dual fuel engine is the gas engine fueled with VOC's (Volatile Organic Compounds) evaporated from the cargo adapted by MAN Diesel in collaboration with Statoil. Because the largest amount of volatile organic compounds is generated during the loading process of crude

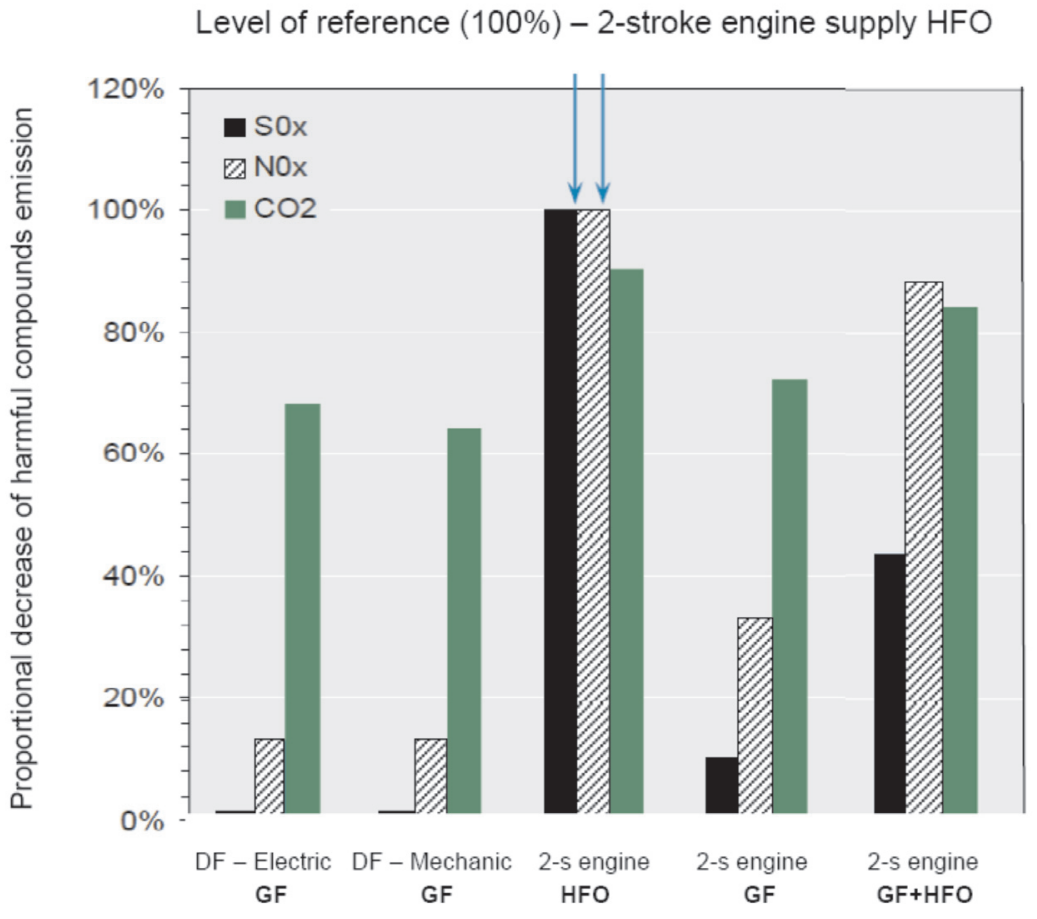

Fig. 12. Comparison of the percentage values of the reduction of the exhaust emissions for different marine powertrain solutions and for fuel gas and heavy fuel oil as compared to the two-stroke engine fueled with heavy fuel oil [3]

Rys. 12. Porównanie procentowych wartości zmniejszenia emisji substancji szkodliwych w przypadku zastosowania różnych rozwiąań układu napędowego statku oraz paliwa gazowego i ciężkiego w stosunku do silnika dwusuwowego zasilanego paliwem ciężkim [3]

\section{Przykłady rozwiązań układów napędowych statków z zastosowaniem silników dwupaliwowych oraz ich wplyw na emisję związków toksycznych w spalinach}

Zastosowanie silników dwupaliwowych (DF - Dual Fuel) wydaje się szczególnie atrakcyjne dla gazowców przewożących skroplony gaz ziemny (LNG), ponieważ odparowany gaz BOG (Boil of Gas) z ładunku wykorzystywany jest jako paliwo do silników. Pozwala to na ograniczenie bardzo skomplikowanego i kosztownego procesu ponownego skraplania gazu oraz na zmniejszenie resztek ładunkowych.

W odniesieniu do gazowców LNG, ze względu na kryteria ekonomiczne, takie jak koszt paliwa, zużycie paliwa, zmniejszenie wymiarów siłowni i w związku z tym zwiększenie objętości ładowni, producenci silników (przede wszystkim firmy MAN Diesel i Wärtsilä) proponują zastosowanie siłowni wyposażonej w zespoły prądotwórcze napędzane silnikami dwupaliwowymi, a wytworzona przez nie energia zasila silnik elektryczny napędzający śrubę napędową statku - siłowni Dual-Fuel-Electric. Przykład takiej siłowni przedstawiono na rys. 9.

Innym rozwiązaniem jest zastosowanie układu Dual-Fuel-Mechanic, w którym dwupaliwowe silniki dwusuwowe lub czterosuwowe napędzają śrubę napędową o nastawnym lub nienastawnym skoku. Przykład rozwiązania siłowni z dwoma dwusuwowymi silnikami wolnoobrotowymi firmy MAN Diesel typu MC-C/ME-C/MEGI napędzającymi dwie śruby napędowe przedstawiono na rys. 10 [2].

Specyficzną formą silnika dwupaliwowego jest zaadaptowany przez firmę MAN 
oil, the evaporated VOC's are collected in special tanks and after purification are condensed for later use in the engine (Fig. 11) [7].

According to [3] the combustion of natural gas in marine engines in comparison to the diesel oil enables:

- a reduction of the emission of carbon monoxide by approximately $75 \%$,

- a reduction of the emission of carbon dioxide by approximately $20 \%$,

- a reduction of the emission of $\mathrm{NO}_{\mathrm{x}}$ by approximately $80 \%$,

- elimination of the emission of sulfuric oxides,

- a reduction of the emission of benzene by approximately $97 \%$,

- a lower emission of particulate matter,

- combustion without a visible smoke.

Apart from very high economic indexes, dual fuel engines are characterized by low exhaust emissions particularly when operating on lean air fuel mixtures of $\lambda=2.1$ [4].

Figure 12 presents a comparison of the percentage changes in the exhaust emissions for different solutions of the powertrains compared with the two-stroke engine fueled with heavy fuel oil:

- Dual-Fuel-Electric system with natural evaporation NBOG and forced evaporation F-BOG,

- Dual-Fuel-Mechanic system with natural evaporation N-BOG and forced evaporation F-BOG,

- two-stroke engine fueled with heavy fuel oil (HFO), twostroke engine fueled with fuel gas (GF), two-stroke engine fueled with fuel gas (GF) and heavy fuel oil (HFO).

\section{Own simulation research of the emission of $\mathrm{NO}_{x}$ from marine dual fuel engines}

Within the research realized By Naval Academy on the exhaust emission of nitric oxides from marine vessels operating on selected waters [8 - 12] that also included dual fuel engines a division of vessels has been performed into 10 categories depending on the type of vessel and six routes
Diesel we współpracy z koncernem paliwowym Statoil silnik gazowy zasilany odparowanymi z ładunku lotnymi związkami organicznymi - VOC's (Volatile Organic Compounds). W związku z tym, że największa ilość lotnych związków organicznych powstaje podczas załadunku surowej ropy naftowej, odparowane VOC's zbierane są w specjalnych zbiornikach i po oczyszczeniu skraplane w celu późniejszego wykorzystania w pracującym silniku (rys. 11) [7].

Według [3] spalanie gazu ziemnego w silnikach okrętowych w porównaniu z olejem napędowym pozwala na:

- zmniejszenie emisji tlenku węgla o ok. 75\%,

- zmniejszenie emisji dwutlenku węgla o ok. $20 \%$,

- zmniejszenie emisji tlenków azotu o ok. 80\%,

- brak emisji tlenków siarki,

- zmniejszenie emisji benzenu o ok. 97\%,

- mniejszą emisję cząstek stałych,

- spalanie bez widocznego dymienia.

Silniki dwupaliwowe charakteryzują się, oprócz bardzo korzystnych wskaźników ekonomicznych, małymi wartościami emisji związków toksycznych w spalinach, zwłaszcza podczas pracy na ubogich mieszankach paliwa z powietrzem $\lambda=2,1[4]$.

Na rysunku 12 przedstawiono porównanie procentowych zmian wartości emisji substancji szkodliwych dla różnych rozwiązań układu napędowego w stosunku do silnika dwusuwowego zasilanego paliwem ciężkim:

- układu napędowego Dual-Fuel-Electric z wykorzystaniem gazu odparowanego naturalnie N-BOG i pozyskanego $\mathrm{w}$ sposób wymuszony F-BOG,

- układu napędowego Dual-Fuel-Mechanic z wykorzystaniem gazu odparowanego naturalnie N-BOG lub pozyskanego w sposób wymuszony F-BOG,

- silnika dwusuwowego zasilanego paliwem ciężkim (HFO), silnika dwusuwowego zasilanego paliwem gazowym (GF), silnika dwusuwowego zasilanego paliwem gazowym (GF) i paliwem ciężkim (HFO).

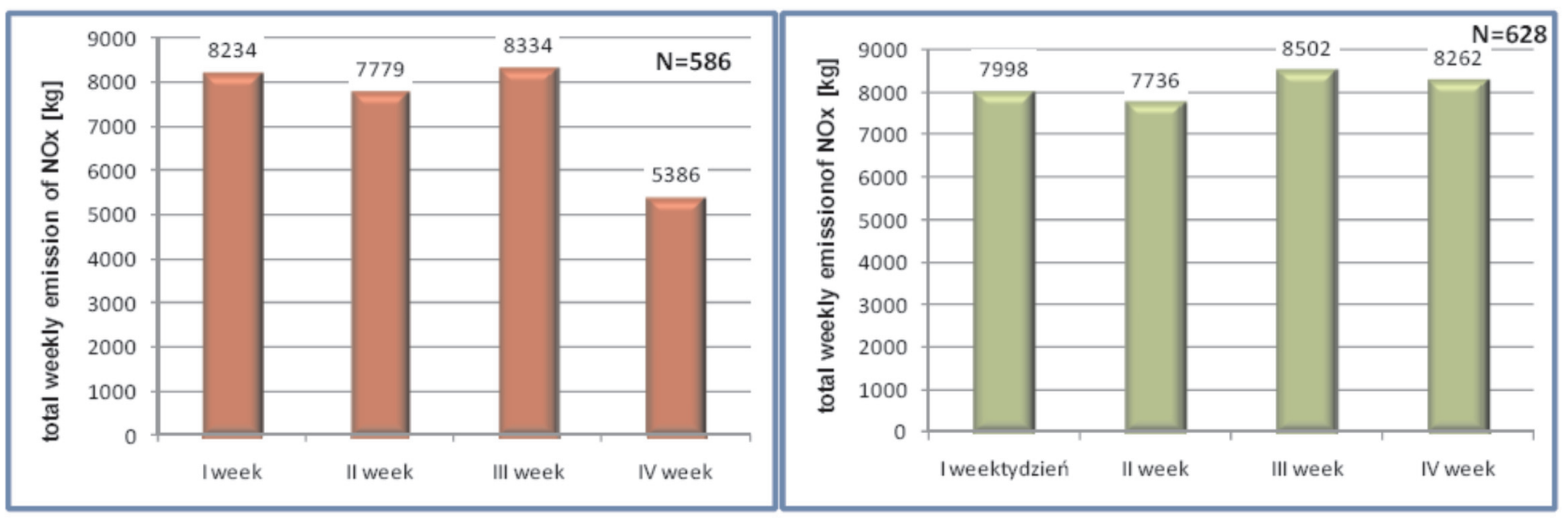

Fig. 13. Comparison of the results of the collective emission rate of nitric oxides [kg/week] in the exhaust gases of marine vessels located in the waters under analysis in the subsequent 28 days of the period under analysis: a) actual statistical data, b) simulation by the Monte Carlo method

Rys. 13. Porównanie wyników sumarycznego natężenia emisji tlenków azotu [kg/tydzień] w spalinach jednostek plywających przebywających $w$ analizowanym obszarze w kolejnych 28 dobach analizowanego okresu: a) rzeczywiste dane statystyczne, b) symulacja metoda Monte Carlo 
were determined of known length ( 3 seaports, 3 fairways direction of the vessel motion included). Utilizing the Monte Carlo method, probabilistic models and computer software were designed that simulated random processes of the parameters related to the motion of a vessel, engine loads and exhaust emissions rate. The authors assumed statistically estimated probability of motion of individual vessels on the fairways. The developed computer software generated the following random variables:

- the vessel's speed,

- the moment of entering the fairway $\tau_{0}$,

- the moment of leaving the fairway $\tau_{1}$,

- the mass of the emitted nitric oxides when on the fairway calculated based on the value of instantaneous power of the main engine of a vessel going at a given speed and the average emission of nitric oxides for this type of engine.

Figure 13 presents the comparison of the results of the weekly emission rate of nitric oxides in the exhaust gases of vessels located in the analyzed waters in subsequent 28 days of the analyzed period. The data were obtained as a result of analysis of the statistical data gathered through the AIS system $[10,12]$ in the period of 12 months as well as through calculations and simulations.

As results from the figure analysis, the differences between the values of the $\mathrm{NO}_{\mathrm{x}}$ emissions calculated based on the statistical data and those based on the simulations are miniscule, which leads to a conclusion that the developed simulation model properly generates both the motion of a vessel and the exhaust emission rate.

Based on the analysis of the results generated through the simulation software it has been observed that in the period assumed for the simulation purposes in one day in the analyzed area of the Bay of Gdansk:

- there were 19 to 22 vessels (maximum 8 of one category), - the highest in number were bulk carriers, general cargo ships, tankers, container ships and LNG carriers.

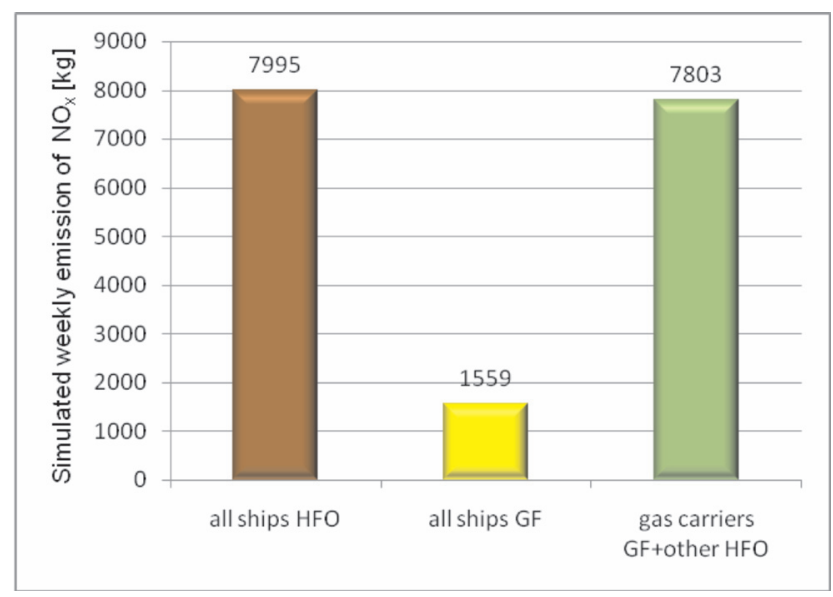

Fig. 14. Simulated values of the collective exhaust emission rate of nitric oxides [ $\mathrm{kg} /$ week] from marine vessels operating in the waters under analysis (type of fuel considered)

Rys. 14. Wartości symulowane sumarycznego natężenia emisji tlenków azotu [kg/tydzień] $w$ spalinach jednostek plywajacych $w$ analizowanym rejonie, z uwzględnieniem rodzaju stosowanego paliwa

\section{Wlasne badania symulacyjne emisji tlenków azotu okrętowych silników dwupaliwowych}

$\mathrm{W}$ ramach realizowanych $\mathrm{w}$ AMW badań [8 - 12] oceny emisji tlenków azotu w spalinach ze statków morskich pływających po określonym akwenie, w tym silników dwupaliwowych, dokonano podziału jednostek pływających na 10 kategorii w zależności od rodzaju statku i określono 6 tras ruchu statków o znanej długości (3 porty, 3 tory wodne $\mathrm{z}$ uwzględnieniem kierunku ruchu statku). Wykorzystując metodę Monte Carlo, skonstruowano probabilistyczne modele i programy komputerowe symulujące procesy losowe parametrów związanych z ruchem statków, obciążeniem silników i natężeniem emisji zanieczyszczeń. Przyjęto przy tym oszacowane statystycznie prawdopodobieństwo ruchu poszczególnych rodzajów jednostek po torach wodnych. Opracowany program komputerowy generował realizacje zmiennych losowych, między innymi:

- prędkości jednostki,

- chwil wejścia na tor wodny $\tau_{0}$,

- chwil opuszczenia toru wodnego $\tau_{1}$,

- masy wyemitowanych tlenków azotu podczas przebywania na torze wodnym obliczonej na podstawie wartości mocy chwilowej silnika głównego statku płynącego z określoną prędkością i średniej wartości emisji tlenków azotu dla tego rodzaju silnika.

Na rysunku 13 przedstawiono porównanie wyników natężenia (tygodniowego) emisji tlenków azotu w spalinach ze statków przebywających w analizowanym obszarze w kolejnych 28 dobach analizowanego okresu, otrzymanych $\mathrm{w}$ rezultacie analizy danych statystycznych pozyskanych za pomocą systemu AIS [10, 12] z okresu 12 miesięcy i obliczeń oraz symulacji.

Jak wynika z analizy rysunku, różnice pomiędzy wartościami emisji tlenków azotu obliczonymi na podstawie danych statystycznych a wartościami symulowanymi są niewielkie, co pozwala sądzić, że opracowany model symulacyjny poprawnie generuje zarówno ruch statków, jak i natężenie emisji związków szkodliwych w ich spalinach.

Na podstawie analizy wyników wygenerowanych za pomocą programu symulacyjnego stwierdzono, że w okresie założonym dla celów symulacji w ciągu jednej doby w badanym rejonie Zatoki Gdańskiej:

- przebywało od 19 do 22 jednostek pływających (maksymalnie $8 \mathrm{z}$ jednej kategorii),

- najwięcej było masowców, drobnicowców, tankowców, kontenerowców oraz gazowców.

Wyniki symulowanej sumarycznej tygodniowej wartości emisji tlenków azotu w spalinach jednostek przebywających $\mathrm{w}$ analizowanym rejonie przedstawiono na rys. 14 . W ramach tej symulacji przyjęto, że:

- wszystkie jednostki napędzane są paliwem ciężkim HFO,

- wszystkie jednostki napędzane są paliwem gazowym GF,

- wszystkie gazowce (12\% ogólnej liczby statków) napędzane są paliwem gazowym GF, pozostałe jednostki - paliwem ciężkim HFO. 
The results of the collective weekly exhaust emission of nitric oxides from vessels operating in the analyzed waters have been presented in Fig. 14. Within this simulation it has been assumed that:

- all vessels are fueled with heavy fuel oil (HFO),

- all vessels are fueled with fuel gas GF,

- all LNG carriers (12\% of the total vessels) are fueled wit fuel gas GF, the other vessels - heavy fuel oil HFO.

As results from the analysis of Fig. 14, the simulated fuel gas application instead of heavy fuel oil led to a collective reduction of the emission of nitric oxides by approximately $80 \%$. This value is only a result of an assumption that all vessels are driven by dual fuel engines of the same average emission of nitric oxides, which is highly improbable in practice. The performance of such a simulation was thus only for the purpose of validating of the model compliance. When the fuel gas was applied only on LNG carriers (19 vessels in the simulated period) the reduction of the simulated emission was approximately $2.4 \%$, which, on a mass scale, is as much as $192 \mathrm{~kg}$ of nitric oxides emitted to the atmosphere by the ships in a period of one week.

\section{Conclusions}

The use of dual fuel engines, particularly on LNG carriers is an advantageous solution in terms of the fuel flexibility (marine fuels MDO and HFO and fuel gas GF), reduction of the cargo residues and losses caused by fuel evaporation, let alone the reduction of the exhaust emissions of nitric oxides. The performed simulation research (the use of fuel gas for fueling of marine engines of vessels operating in the area of Bay of Gdansk) has shown positive ecological results.
Jak wynika z analizy rys. 14, symulowane zastosowanie paliwa gazowego zamiast paliwa ciężkiego spowodowało sumaryczne zmniejszenie natężenia emisji tlenków azotu o ok. $80 \%$. Wartość ta jest jednak tylko wynikiem założeń, według których wszystkie jednostki byłyby napędzane silnikami dwupaliwowymi o takiej samej średniej wartości emisji tlenków azotu, co w praktyce jest mało prawdopodobne. Przeprowadzenie takiej symulacji miało więc znaczenie jedynie w sprawdzeniu zgodności modelu. Gdy zastosowano paliwo gazowe tylko na gazowcach (19 jednostek w symulowanym okresie), zmniejszenie symulowanej emisji wyniosło ok. 2,4\%, co jednak w skali masowej stanowi aż $192 \mathrm{~kg}$ tlenków azotu niewyemitowanych w ciągu tygodnia do atmosfery przez statki.

\section{Podsumowanie}

Zastosowanie silników dwupaliwowych, zwłaszcza na gazowcach LNG, jest rozwiązaniem korzystnym zarówno pod względem elastyczności wyboru rodzaju paliwa (paliwa okrętowe MDO i HFO oraz paliwo gazowe GF), ograniczania resztek ładunkowych i strat spowodowanych parowaniem paliwa, jak również pod kątem ograniczania emisji tlenków azotu w spalinach. Przeprowadzone badania symulacyjne zastosowania paliwa gazowego do zasilania silników na statkach pływających w rejonie Zatoki Gdańskiej wykazały korzystne efekty ekologiczne.

Paper reviewed/Artykut recenzowany

\section{Bibliography/Literatura}

[1] Włodarski J.K., Witkowski K.: Okrętowe silniki spalinowe. Wydawnictwo Akademii Morskiej, Gdynia 2006.

[2] Materiały firmy MAN: www.mandiesel.com

[3] Materiały firmy Wärtsilä: www.Wartsila.com/LNG

[4] Sutkowski M., Latvasalo T.: The 20V23SG - a high-efficiency Lean-burn gas engine for highly efficient Wartsila gas power plants. Combustion Engines, 2007, No SC1.

[5] Żmudzki S.: Perspektywy wykorzystania gazu ziemnego w silnikach okrętowych. Zeszyty Naukowe Akademii Morskiej w Szczecinie, 2004, nr 1(73).

[6] Jarf C., Sutkowski M.: The Wärtsilä 32 GD engine for heavy gases. Combustion Engines, 2009, No 2.

[7] Challen B., Baranescu R., Diesel Engine. Reference Book. Butterworth Heinemann, Oxford 1999.

[8] Kniaziewicz T.: Problemy modelowania imisji szkodliwych składników spalin z silników okrętowych w rejonach miejskich

Prof. Leszek Piaseczny, DSc, DEng. - Professor in the Mechanical-Electric Faculty at Naval University of Gdynia.

Prof. dr hab. inż. Leszek Piaseczny - profesor na Wydziale Mechaniczno-Elektrycznym Akademii Marynarki Wojennej w Gdyni.

e-mail: piaseczny@ptnss.pl

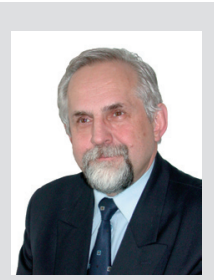

aglomeracji nadmorskich. Zeszyty Naukowe Politechniki Częstochowskiej 162, Mechanika 26, Częstochowa 2006.

[9] Kniaziewicz T., Piaseczny L.: Model of NOx emission by sea-going vessels navigating in the Gulf of Gdansk region. Combustion Engines, 2007, No. SC3.

[10] Kniaziewicz T., Piaseczny L.: Stochastic models of toxic compounds emission in exhausts from sea-going vessels sailing in a particular area. Combustion Engines, 2009, No. SC1.

[11] Kniaziewicz T., Piaseczny L.: Modelowanie emisji gazów spalinowych w transporcie morskim. Logistyka, nr 4/2010, s. 18-26.

[12] Pawlak M., Piaseczny L.: Modelowanie ruchu jednostek morskich dla określania emisji związków toksycznych spalin. Materiały Międzynarodowej Konferencji Motoryzacyjnej KONMOT-AUTOPROGRES 2008, Szczawnica 2008.

Tomasz Kniaziewicz, DEng. - doctor in the Faculty of Mechanical and Electrical Engineering at Polish Naval Academy of Gdynia.

Dr inż. Tomasz Kniaziewicz - adiunkt na Wydziale Mechaniczno-Elektrycznym Akademii Marynarki Wojennej w Gdyni.

e-mail: tkniaziewicz@wp.pl 